\title{
Scrap Tire Recycling
}

Federal Manufacturing \& Technologies

James W. Lula and George W. Bohnert

MAY 12497

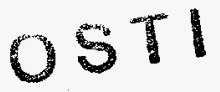

KCP-613-5925

Published March 1997

Final Report/Project Accomplishments Summary CRADA Number 95-KCP-1021

Approved for public release; distribution is unlimited.

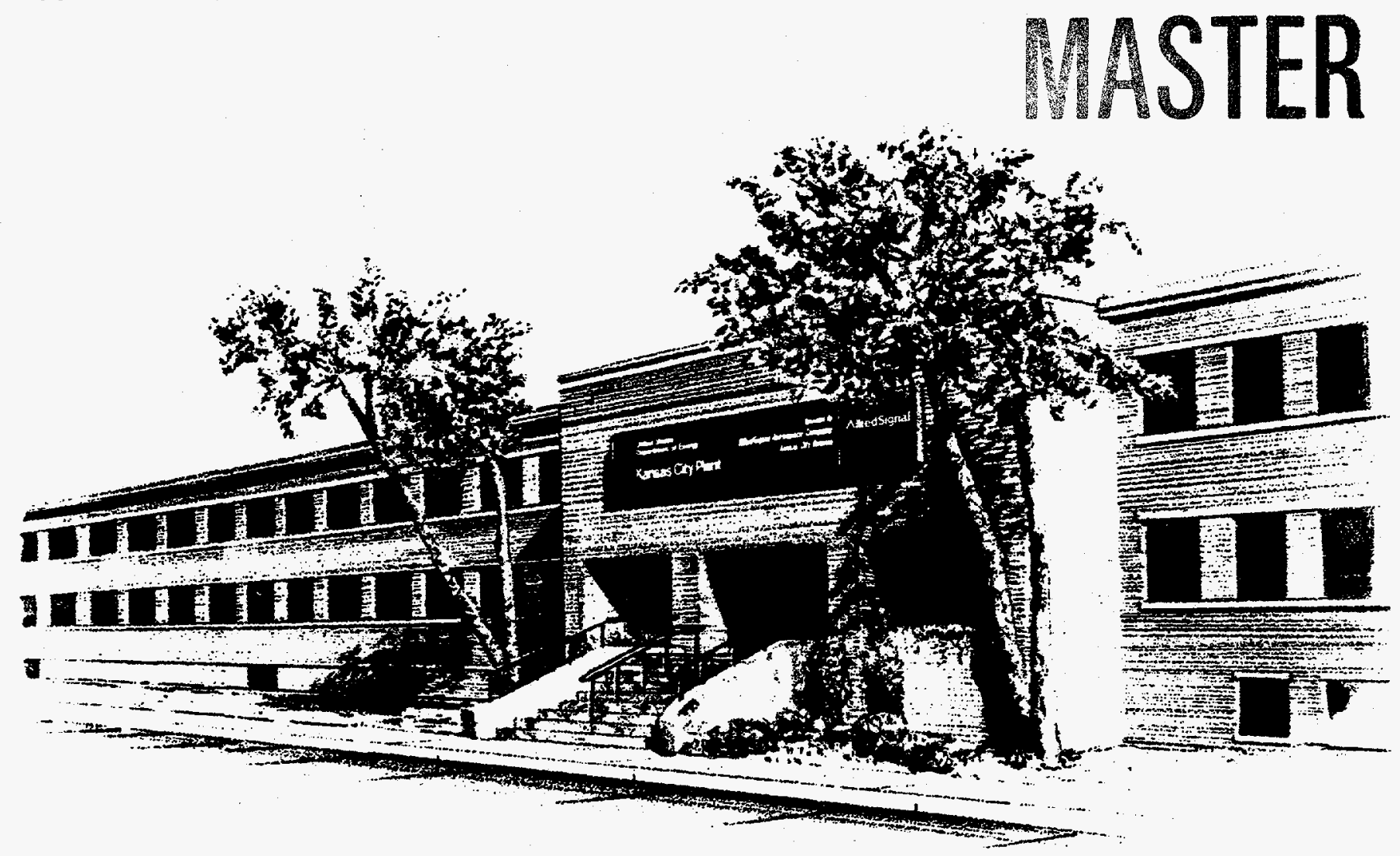

DISTRIBUTION OF THIS DOCUMENT IS UNLIMITED

Prepared Under Contract Number DE-ACO4-76-DP00613 for the United States Department of Energy

AlliedSignal

A E R O S P A C E 


\section{DISCLAIMER}

This report was prepared as an account of work sponsored by an agency of the United States Government. Neither the United States Government nor any agency thereof, nor any of their employees, makes any warranty, express or implied, or assumes any legal liability or responsibility for the accuracy, completeness, or usefulness of any information, apparatus, product, or process disclosed, or represents that its use would not infringe privately owned rights. Reference herein to any specific commercial product, process, or service by trade names, trademark, manufacturer, or otherwise, does not necessarily constitute or imply its endorsement, recommendation, or favoring by the United States Government or any agency thereof. The views and opinions of authors expressed herein do not necessarily state or reflect those of the United States Government or any agency thereof.

Printed in the United States of America.

This report has been reproduced from the best available copy.

Available to DOE and DOE contractors from the Office of Scientific and Technical Information, P. O. Box 62, Oak Ridge, Tennessee 37831; prices available from (615) 576-8401, FTS 626-8401.

Available to the public from the National Technical Information Service, U. S. Department of Commerce, 5285 Port Royal Rd., Springfield, Virginia 22161.

A prime contractor with the United States Department of Energy under Contract Number DE-ACO4-76-DP00613.
AlliedSignal Inc. Federal Manufacturing \& Technologies

P. O. Box 419159 Kansas City, Missouri 64141-6159 
KCP-613-5925

Distribution Category UC-706

Approved for public release; distribution is unlimited.

SCRAP TIRE RECYCLING

James W. Lula and

George W. Bohnert

Published March 1997

Final Report/Project Accomplishments Summary

CRADA Number 95-KCP-1021 


\section{DISCLAMMER}

\section{Portions of this document may be illegible}

in electronic image products. Images are produced from the best available original document. 


\section{DISCLAIMER}

This report was prepared as an account of work sponsored by an agency of the United States Government. Neither the United States Government nor any agency thereof, nor any of their employees, make any warranty, express or implied, or assumes any legal liability or responsibility for the accuracy, completeness, or usefulness of any information, apparatus, product, or process disclosed, or represents that its use would not infringe privately owned rights. Reference herein to any specific commercial product, process, or service by trade name, trademark, manufacturer, or otherwise does not necessarily constitute or imply its endorsement, recommendation, or favoring by the United States Government or any agency thereof. The views and opinions of authors expressed herein do not necessarily state or reflect those of the United States Government or any agency thereof. 


\section{Scrap Tire Recycling \\ Project Accomplishments Summary \\ CRADA Number 95-KCP-1021}

Date: $1 / 27 / 97$

\section{A. Parties}

The project is a relationship between

AlliedSignal FM\&T

2000 E $95^{\text {th }}$ Street

PO Box 419159

Kansas City, MO 64141-6159
Revision: 0

\author{
Recycled Rubber Resources \\ 1600 Blees Industrial Dr. \\ Macon, MO 63552
}

\section{B. Background}

As the automobile tire technology has grown and met the need for safer and more durable tires, stronger reinforcement and more chemically resistant rubber compounds have made recycling tires more difficult. Combined with a lessening demand for reclaimed rubber in new tires, this change had resulted in a gradual decline in the percentage of rubber recycled. By 1960 , only about $20 \%$ of rubber products, including tires, were recycled. The introduction of steel-belted radial tires in the 1960s complicated the tire grinding process and led to a further reduction of the recycled content of rubber products to about $2 \%$.

At this point in time, lacking a viable reclamation process and end use, scrap tires began to accumulate in the environment. Illegally dumped tires became an increasingly stubborn problem, leading to uncontrollable fires and insect breeding grounds. In an effort to resolve this problem, techniques and equipment were developed to grind tires into small pieces, and new markets were sought to utilize the crumb rubber product streams from ground tires. Industrial combustion processes were modified to accept scrap tires as fuel. These efforts have been beneficial, steadily increasing the percentage of scrap tires recycled to about $10 \%$ in 1985 , and reaching $72 \%$ in 1995 . By the end of 1997 , fully $100 \%$ of tires generated in the U.S. are expected to be recycled.

Of the approximately 250 million scrap tires generated annually in the U.S., the principal market is tire derived fuel (TDF). Properly handled, TDF is cheaper than coal, burns cleaner, and generates positive public relations. In 1995, approximately 130 million tires were consumed as TDF by cement kilns, pulp/paper mills, industrial boilers, electric power utilities, and dedicated tire-toenergy facilities.

Beșides TDF, other uses of scrap tires include civil engineering applications such as retaining walls, roadfill, and artificial reefs. In 1995, these uses accounted for about 15 million scrap tires. Another 2.5 million scrap tires were destined for use in agriculture, and 12.5 million tires were exported. Finally, approximately 
20 million scrap tires were ground into crumb rubber for asphalt blending, compounding in new tires, various molded rubber products, playground/athletic surfaces, and friction materials. Ground crumb rubber for these types of products and applications is the focus of Recycled Rubber Resources, Inc.

At this project's inception, only the ground crumb rubber was a marketable product, leaving the wire and synthetic fiber to be land filled. FM\&T's experience in material composition and particle size analysis was used to focus on these waste streams. FM\&T's experience in material formulation was used to experiment with potential products from the crumb rubber and synthetic fiber streams.

\section{Description}

Recycled Rubber Resources (RRR) is a small business located in Macon, MO, incorporated in September 1993 for the purpose of grinding and recycling scrap tires. RRR primarily processes whole scrap tires, but also accepts non-tire rubber scrap material. The core business is custom grinding high-quality crumb rubber for the customer's specification of mesh size and product purity.

As a start-up company in an emerging industry, RRR has developed its process to produce very clean, fiber-free, high quality crumb rubber of various particle sizes. Focusing on the crumb rubber as the primary marketable product, the steel wire and tire cord fiber were initially landfilled. However, efforts to market the steel wire and fiber have continued, with promising outlets for each. Understandably, by reducing the amount of material landfilled, the operating costs for the business are also reduced. The objective of this project was to characterize the crumb rubber, synthetic fiber, and steel wire product streams, determining where improvements could be made in the grinding/separation process that increases the product value and lowers the operating cost. In this manner, the company will offer a higher quality product, become more competitive, and help resolve an environmental problem.

RRR and FM\&T worked together to minimize the amount of landfilled material from the tire grinding process. Specifically, FM\&T identified large quantities of rubber in the fiber waste stream. RRR purchased and installed additional equipment to recover this rubber. Because the fiber was cleaner (less rubber), a market was found for the fiber. Additionally, FM\&T suggested a technique to clean the steel wire. RRR is scaling up this suggestion for production-sized quantities. 


\section{Expected Economic Impact}

The results of this project have enabled Recycled Rubber Resources to grind tires more efficiently, producing higher quality crumb rubber and minimizing scrap material, such as steel wire and synthetic fiber, that previously went to a landfill. Economic benefits resulting from these process improvements include more job opportunities for local residents, as the company has had to expand operations to three shifts, nearly doubling the workforce from 14 to 27 employees. To supply RRR with raw material, jobs also have opened up for those in the business of collecting and disposing of scrap tires. Finally, process improvements have required capital equipment purchases amounting to $\$ 80,000$ in 1996.

\section{E. Benefits to DOE}

This project has enhanced the skills of FM\&T technical staff in areas of composite fabrication such as particle separation, rubber compounding, extrusion, and injection molding. Skills also were enhanced in areas of material testing including particle size analysis, mechanical strength, thermal properties, and ash content.

\section{F. Industry Area}

The industries benefiting from this project include the automotive (crumb rubber in new tires), railroad (synthetic fiber in brakes), basic steel (remelting scrap steel wire), and manufacturers of molded rubber articles.

\section{G. Project Status}

This project was completed as scheduled.

\section{H. Point of Contact for Project Information}

Ken Bauer

US Department of Energy

Kansas City Area Office

PO Box 410202

Kansas City, MO 64141-0202

Telephone: (816) 997-3917

Fax: (816) 997-5059
James W. Lula, George W. Bohnert

AlliedSignal FM\&T

PO Box 419159

Kansas City, MO 64141-6159

Telephone: (816) 997-2417

Fax (816) 997-2049

\section{Company Size and Point of Contact}

Recycled Rubber Resources is a small business of approximately 30 employees.

Half of these employees have been added during the life of this CRADA. The point of contact at Recycled Rubber Resources is Matt DeBasio [(816) 385$7156]$. The crumb rubber production of RRR initially was 15,000 pounds per month. Steady improvements in grinding and separation processes have 
enabled crumb rubber production to increase to the current levels in excess of 1 million pounds/month. This level of production has enabled the company to expand to three working shifts.

\section{J. Project Examples}

The main result of this project is increased production of crumb rubber at RRR, coupled with less material (steel wire and synthetic fiber) that is going to the landfill. However, during the course of the project, a limited number of test samples have been molded using crumb rubber in combination with agriculturalbased plasticizing oils and thermoplastic elastomers.

\section{K. Technology Commercialization}

As a result of this project, a substantial amount of crumb rubber was identified in the fiber waste stream. FM\&T proposed a method to recover this material and RRR purchased the necessary capital equipment. With this additional equipment, RRR recovers an additional 50,000 pounds/month of crumb rubber. 


\section{Release of Information}

I have reviewed the attached Project Accomplishment Summary prepared by AlliedSignal FM\&T and agree that the information about our CRADA may be released for external distribution.

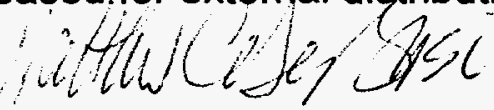

Name: Matthew C. DeBasio

Organization: RRR, LLC

Title: President \& CEO

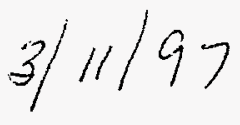

